\title{
Use of molecular markers to compare Fusarium verticillioides pathogenic strains isolated from plants and humans
}

\author{
S.C. Chang ${ }^{1}$, D.P.C. Macêdo ${ }^{2}$, C.M. Souza-Motta ${ }^{3}$ and N.T. Oliveira' ${ }^{1}$ \\ ${ }^{1}$ Laboratório de Genética Molecular de Fungos, Departamento de Micologia, \\ Universidade Federal de Pernambuco, Recife, PE, Brasil \\ ${ }^{2}$ Laboratório de Micologia Médica, Departamento de Micologia, \\ Universidade Federal de Pernambuco, Recife, PE, Brasil \\ ${ }^{3}$ Micoteca URM, Departamento de Micologia, \\ Universidade Federal de Pernambuco, Recife, PE, Brasil \\ Corresponding author: S.C. Chang \\ E-mail: suzycchang@yahoo.com.br
}

Genet. Mol. Res. 12 (3): 2863-2875 (2013)

Received November 27, 2012

Accepted April 11, 2013

Published August 12, 2013

DOI http://dx.doi.org/10.4238/2013.August.12.2

\begin{abstract}
Fusarium verticillioides is a pathogen of agriculturally important crops, especially maize. It is considered one of the most important pathogens responsible for fumonisin contamination of food products, which causes severe, chronic, and acute intoxication in humans and animals. Moreover, it is recognized as a cause of localized infections in immunocompetent patients and disseminated infections among severely immunosuppressed patients. Several molecular tools have been used to analyze the intraspecific variability of fungi. The objective of this study was to use molecular markers to compare pathogenic isolates of $F$. verticillioides and isolates of the same species obtained from clinical samples of patients with Fusarium mycoses. The molecular markers that we used were intersimple sequence repeat markers (primers $\mathrm{GTG}_{5}$ and $\mathrm{GACA}_{4}$ ), intron splice site primer (primer EI1), random amplified polymorphic DNA marker (primer OPW-6), and restriction fragment length polymorphism-internal
\end{abstract}


transcribed spacer (ITS) from rDNA. From the data obtained, clusters were generated based on the UPGMA clustering method. The amplification products obtained using primers ITS4 and ITS5 and loci ITS1-5.8-ITS2 of the rDNA yielded fragments of approximately $600 \mathrm{bp}$ for all the isolates. Digestion of the ITS region fragment using restriction enzymes such as EcoRI, DraI, BshI, AluI, HaeIII, HinfI, MspI, and Pst did not permit differentiation among pathogenic and clinical isolates. The inter-simple sequence repeat, intron splice site primer, and random amplified polymorphic DNA markers presented high genetic homogeneity among clinical isolates in contrast to the high variability found among the phytopathogenic isolates of $F$. verticillioides.

Key words: Fusarium verticillioides; ISSR; Intron; RAPD

\section{INTRODUCTION}

Corn (Zea mays L.) is a crop of great socio-economic significance in Brazil. Every year, the country produces about 50 million tons of grain. In fact, in 2008, corn production reached more than 59 million tons, with the State of Paraná accounting for $26.5 \%$ of it (Ramos, 2008; IBGE, 2009).

Fusarium verticillioides Sacc. Nirenberg (= Fusarium moniliforme Sheldon) is a nonobligate parasite, which infects important crops such as sorghum, sugarcane, and maize. It occurs worldwide, both in the soils of tropical and subtropical regions, as well as humid and sub-humid temperate zones (Figueira, 2003; Meirelles, 2005; Bernd, 2006). F. verticillioides is probably the most common pathogen of maize crops throughout the world - it causes stalk, root, ear, and kernel rot, and seedling blight (Meirelles, 2005). This pathogen may cause damage during all stages of plant development by infecting the roots, stem, and grain, although in most cases, the infection is asymptomatic and can be characterized as an endophytic relationship (Pamphile and Azevedo, 2002; Mirete et al., 2004; Sartori et al., 2004; Bacon et al., 2008).

F. verticillioides has also been reported to be the etiological agent of superficial and disseminated infections in humans. Fungal infections are considered relevant, especially in immunosuppressed patients, and are frequently associated with high morbidity and mortality (Pamphile and Azevedo, 2002; Mirete et al., 2004; Sartori et al., 2004; Tezcan et al., 2009).

F. verticillioides has the ability to produce several types of mycotoxins, including moniliformin, fusariocin, fusarona $\mathrm{C}$, fusaric acid, and fumonisin, and is considered to be one of the most important global sources of contamination in food products that are derived from maize and other types of grains (Marasas et al., 1986; Bacon and Hinton, 1996; Mirete et al., 2004).

Taxonomically, F. verticillioides belongs to the Liseola section of the Gibberella fujikuroi (Sawada) Wolenw. complex, which is a teleomorph that is associated with Fusarium isolates of this section. It is subdivided into at least 8 genetically distinct biological species or mating populations and is identified by the letters $\mathrm{A}$ to $\mathrm{H}$. The mating populations $\mathrm{A}$ and D produce high levels of mycotoxins, while the others produce few or none (Schiabel, 2004; Meirelles, 2005). F. verticillioides corresponds to the biological population A. Patiño et al. (2006) demonstrated that taxonomic studies on this complex are highly controversial and that the complex totals approximately 36 species using only morphological tools. 
Several techniques have been used to assess the intraspecific variability in F. verticillioides: restriction fragment length polymorphism-internal transcribed spacer (RFLP-ITS) from rDNA (Patiño et al., 2006; Dissanayake et al., 2009); random amplified polymorphic DNA (RAPD; Nagarajan et al., 2006; Singh et al., 2006; Bayraktar et al., 2008), inter-simple sequence repeat (ISSR; Luongo et al., 2007; Bayraktar et al., 2008); amplified fragment length polymorphism (AFLP; Reynoso et al., 2009); intron splice site primer (ISSP; Brasileiro et al., 2004).

Given the relevance of molecular methods in analyzing genetic variability, our study aimed to analyze and genetically compare $F$. verticillioides isolates that were obtained from plants and clinical samples using the RFLP of the ITS region, as well as ISSP (EI1), RAPD (OPW-6), and ISSR ( $\mathrm{GTG}_{5}$ and $\left.\mathrm{GACA}_{4}\right)$ molecular markers.

\section{MATERIAL AND METHODS}

\section{Fungal strains}

Sixteen isolates of F. verticillioides (6 from clinical samples of patients with Fusarium mycoses of which 9 were phytopathogenic and 1 was endophytic) were provided by the Culture Collection, University of Recife - Mycology (URM) of the Mycology Department, Universidade Federal de Pernambuco (Table 1). F. oxysporum and $F$. solani strains were used as the outgroup for comparative analysis of the genetic variability of the 16 isolates.

\begin{tabular}{lll}
\multicolumn{1}{c}{ Table 1. Fusarium isolates according to host origin. } \\
\hline Fusarium species & Accession No. (URM collection) & \\
\hline F. verticillioides & URM5352 & Substrate or host \\
& URM3278 & Zea mays \\
& URM3007 & Sorghum bicolor L. Moench \\
& URM5094 & Root of Oryza sativa \\
& URM3096 & Endophytic of Saccharum officinarum \\
URM2388 & Alibertia myrciifolia leaf \\
URM2542 & S. officinarum \\
URM2387 & Z. mays \\
URM2495 & S. officinarum \\
URM2241 & Sorghum bicolor L. Moench \\
& URM5390 & S. officinarum \\
URM5284 & Face lesion \\
URM5354 & Nose biopsy \\
F. solani & URM4051 & Leg lesion \\
F. oxysporum & URM5285 & Nails \\
\hline
\end{tabular}

\section{Fungal growth and DNA extraction}

Fusarium isolates were maintained in potato dextrose agar medium for 7 days at room temperature. The conidia of each isolate were suspended in $3 \mathrm{~mL} 0.1 \%$ Tween $80\left(\mathrm{v} / \mathrm{v} ; 10^{6}\right.$ conidia/mL) and transferred to Erlenmeyer flasks that contained $100 \mathrm{~mL}$ liquid potato dextrose agar medium. The flasks were shaken at $27 \mathrm{rpm}$ for $120 \mathrm{~h}$ at $28^{\circ} \mathrm{C}$ to perpetuate fungal growth. Subsequently, the mycelia were collected by vacuum filtration and washed with distilled water that was autoclaved. The wet weights were determined and the samples were stored at $-20^{\circ} \mathrm{C}$. 
DNA was extracted following the technique described by Kuramae-Izioka (1997) using liquid nitrogen until mycelia were completely pulverized. It was then transferred to microtubes that contained $700 \mu \mathrm{L}$ extraction buffer $(1 \mathrm{M}$ Tris- $\mathrm{HCl}, \mathrm{pH} 8.0 ; 250 \mathrm{mM} \mathrm{NaCl} ; 0.5$ mM EDTA, pH 8.0; 10\% sodium dodecyl sulfate). After homogenization, the microtubes were incubated at $65^{\circ} \mathrm{C}$ for $30 \mathrm{~min}$ and gently shaken by inversion every $10 \mathrm{~min}$. Next, $500 \mu \mathrm{L} 5$ $\mathrm{M}$ potassium acetate was added, followed by homogenization and centrifugation at 14,500 $g$ for $10 \mathrm{~min}$. Each supernatant was extracted with chloroform-isoamyl alcohol (24:1), and centrifugation was carried out at $14,500 \mathrm{~g}$ for $10 \mathrm{~min}$. One volume of isopropanol was added to each recovered aqueous phase, and the mixture was cooled at $4^{\circ} \mathrm{C}$ for $3 \mathrm{~h}$ to precipitate the DNA. Then, DNA samples were centrifuged at $14,500 \mathrm{~g}$ for $10 \mathrm{~min}$. The precipitates were washed with $70 \%$ ethanol, centrifuged for $10 \mathrm{~min}$, dried at room temperature, resuspended in Tris-EDTA buffer, $\mathrm{pH} 8.0$ (1 M Tris- $\mathrm{HCl}$ and $0.5 \mathrm{M}$ EDTA), and stored in a freezer at $-20^{\circ} \mathrm{C}$.

The DNA concentration was estimated by electrophoresis on a $0.8 \%$ agarose gel at $3 \mathrm{~V} /$ $\mathrm{cm}$ distance between the electrodes with $1 \mathrm{X}$ Tris-borate-EDTA (TBE) running buffer in comparison with a lambda phage DNA molecular weight marker (Invitrogen Life Technologies, Brasil). After electrophoresis, the gel was stained in ethidium bromide solution (1X TBE/0.5 $\mu \mathrm{g} /$ $\mathrm{mL}$ ethidium bromide; Sambrook et al., 1989) for $30 \mathrm{~min}$, observed using an ultraviolet transilluminator, and photographed using a digital camera (effective resolution, 7.2 megapixels).

\section{RFLP-ITS from rDNA}

Amplification reactions were performed in a final volume of $25 \mu \mathrm{L}$ that contained $1 \mathrm{X}$ Taq buffer (20 mM Tris-HCl, pH 8.4, and $50 \mathrm{mM} \mathrm{KCl}$ ), $1.5 \mathrm{mM} \mathrm{MgCl}, 0.2 \mathrm{mM}$ dNTP, 0.5 $\mathrm{mM}$ each of ITS4 and ITS5 primers (Table 2), $0.04 \mathrm{U}$ Taq DNA polymerase (Invitrogen Life Technologies), and 25 ng DNA, as described by White et al. (1990). A thermal cycler was used with the following schedule: initial denaturation at $95^{\circ} \mathrm{C}$ for $4 \mathrm{~min} ; 40$ cycles of $92^{\circ} \mathrm{C}$ for $1 \mathrm{~min}, 55^{\circ} \mathrm{C}$ for $1 \mathrm{~min}$, and $72^{\circ} \mathrm{C}$ for $2 \mathrm{~min}$; and a final extension for $5 \mathrm{~min}$ at $72^{\circ} \mathrm{C}$. Amplified products of the locus ITS1-5.8S-ITS2 of the rDNA were separated by electrophoresis on a $1.0 \%$ agarose gel at $3 \mathrm{~V} / \mathrm{cm}$ in $1 \mathrm{X}$ TBE buffer, $\mathrm{pH} 8.0$, using a 100-bp molecular weight marker (Invitrogen Life Technologies). After electrophoretic migration, the gel was stained in ethidium bromide solution for $30 \mathrm{~min}$, visualized by using an ultraviolet transilluminator, and photographed with a digital camera (effective resolution, 7.2 megapixels).

Table 2. Primers used to analyze the genetic diversity of Fusarium isolates.
\begin{tabular}{llll}
\hline Primer & Sequence (5'-3') & Molecular marker & Reference/Supplied \\
\hline ITS4 & TCCTCCGCTTATTGATATGC & ITS & White et al. (1990) \\
ITS5 & GGAAGTAAAGTCGTAACAA & ITS & White et al. (1990) \\
EI1 & CTGGCTTGGTGTATGT & ISSP & de Barros Lopes et al. (1996) \\
$(\text { GTG })_{5}$ & GTGGTGGTGGTGGTG & ISSR & Lieckfeldt et al. (1993) \\
$(\text { GACA })_{4}$ & GACAGACAGACAGACA & ISSR & Meyer and Mitchel (1995) \\
OPW-6 & AGGCCCGATG & RAPD & Operon Technologies, Inc. \\
\hline
\end{tabular}

Aliquots of $4 \mu \mathrm{L}$ amplicons were subjected to enzymatic digestion with EcoRI, DraI, and BshI, HaeIII, MspI, HinfI, PstI, and AluI, separately, according to manufacturer instructions. Fragments were separated on $1.5 \%$ agarose gel (w/v) using a 100-bp molecular weight marker (Invitrogen Life Technologies) 


\section{ISSP and ISSR reactions}

DNA samples were subjected to PCR with EI1, $(\mathrm{GTG})_{5}$, and (GACA) $)_{4}$ primers (Table 2). For the first primer, amplification reactions were performed in a final volume of 25 $\mu \mathrm{L}$ under the following conditions: $1 \mathrm{X}$ buffer $(20 \mathrm{mM}$ Tris- $\mathrm{HCl}, \mathrm{pH} 8.4$, and $50 \mathrm{mM} \mathrm{KCl})$, $1.5 \mathrm{mM} \mathrm{MgCl}, 0.25 \mathrm{mM} \mathrm{dNTP}, 0.5 \mathrm{mM}$ primer, $0.04 \mathrm{U}$ Taq DNA polymerase (Invitrogen Life Technologies), and $25 \mathrm{ng}$ DNA. The amplification proceeded as follows: an initial denaturation step at $94^{\circ} \mathrm{C}$ for $3 \mathrm{~min} ; 40$ cycles of $1 \mathrm{~min}$ at $94^{\circ} \mathrm{C}, 2 \mathrm{~min}$ at $45^{\circ} \mathrm{C}, 1 \mathrm{~min}$ and $30 \mathrm{~s}$ at $74^{\circ} \mathrm{C}$; and a final extension of $5 \mathrm{~min}$ at $74^{\circ} \mathrm{C}$. For the ISSR primers $(\mathrm{GTG})_{5}$ and (GACA), amplification reactions were performed in a final volume of $25 \mu \mathrm{L}$ under the following conditions: $1 \mathrm{X}$ buffer (20 mM Tris- $\mathrm{HCl}, \mathrm{pH} 8.4$ and $50 \mathrm{mM} \mathrm{KCl}$ ), $0.75 \mathrm{mM} \mathrm{MgCl}, 0.25 \mathrm{mM}$ dNTP, $0.25 \mathrm{mM}$ primer, $0.04 \mathrm{U}$ Taq DNA polymerase (Operon Technologies, Alameda, CA, USA), and $25 \mathrm{ng}$ DNA. The amplification cycles consisted of an initial denaturation at $93^{\circ} \mathrm{C}$ for $5 \mathrm{~min} ; 40$ cycles of $20 \mathrm{~s}$ at $93^{\circ} \mathrm{C}, 45 \mathrm{~s}$ at $55^{\circ} \mathrm{C}$, and $90 \mathrm{~s}$ at $72^{\circ} \mathrm{C}$; and a final extension of $6 \mathrm{~min}$ at $72^{\circ} \mathrm{C}$. The amplified products were separated by electrophoresis on a $1.4 \%$ agarose gel at $3 \mathrm{~V} / \mathrm{cm}$ in $1 \mathrm{X}$ TBE running buffer, $\mathrm{pH} 8.0$, using a 100-bp molecular weight marker (Invitrogen Life Technologies). Then, the gel was stained in ethidium bromide solution for $30 \mathrm{~min}$, visualized by using an ultraviolet transilluminator, and photographed with a digital camera (effective resolution, 7.2 megapixels).

\section{RAPD reactions}

Initially, a selection was made from 12 arbitrary oligonucleotide primers from Operon Technologies (OPW, OPA, and OPX kits) with the total DNA of the isolate URM3278 to amplification quality with each of them. From these, primer OPW-6 was selected (Table 2). The amplification reactions were conducted in a final volume of $25 \mu \mathrm{L}$ under the following conditions: $1 \mathrm{X}$ buffer (20 mM Tris- $\mathrm{HCl}, \mathrm{pH} 8.4$, and $50 \mathrm{mM} \mathrm{KCl}), 3.4 \mathrm{mM} \mathrm{MgCl}, 0.25 \mathrm{mM}$ dNTP, $0.5 \mathrm{mM}$ primer, $0.5 \mathrm{U}$ Taq DNA polymerase (Operon Technologies), and $25 \mathrm{ng}$ DNA. The amplification cycles consisted of an initial denaturation at $94^{\circ} \mathrm{C}$ for $5 \mathrm{~min} ; 40$ cycles of $1 \mathrm{~min}$ at $94^{\circ} \mathrm{C}, 1 \mathrm{~min}$ at $36^{\circ} \mathrm{C}$, and $2 \mathrm{~min}$ at $72^{\circ} \mathrm{C}$; and a final extension of $5 \mathrm{~min}$ at $72^{\circ} \mathrm{C}$. The amplified products were separated by electrophoresis on a $1.4 \%$ agarose gel at $3 \mathrm{~V} / \mathrm{cm}$ in $1 \mathrm{X}$ TBE running buffer, $\mathrm{pH} 8.0$, using a 100-bp molecular weight marker (Invitrogen Life Technologies).

\section{Statistical analysis}

The data obtained were analyzed by the Numerical Taxonomy System of Multivariate Programs - NTSYSpc 2.1 (Rohlf, 1988; Bussab et al., 1990) using the Jaccard coefficient. A dendrogram was generated by using the UPGMA clustering method.

\section{RESULTS}

Amplification with primers ITS5 and ITS4 produced one fragment of approximately $600 \mathrm{bp}$ in size for all the clinical and phytopathogenic $F$. verticillioides, $F$. oxysporum, and $F$. solani isolates (Figure 1). 


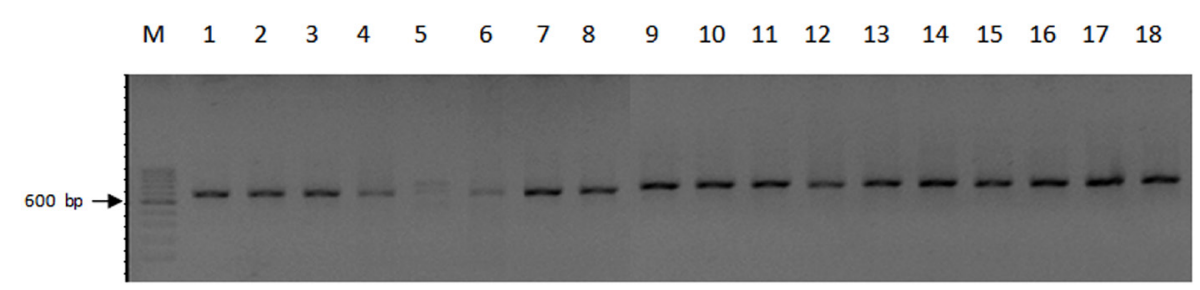

Figure 1. Profiles of amplification of rDNA-internal transcribed spacer(ITS) region of the Fusarium isolates obtained with ITS4 and ITS5 primers. Lane $M=100$-bp ladder; lanes 1-8 = phytopathogenic strains of $F$. verticillioides: URM5352, 3728, 3007, 5094, 3096, 2388, 2542, 2387; lanes 9-14 = clinical strains of $F$. verticillioides: 5390, 5284, 5354, 4951, 5285, FV; Lanes 15 and 16 = phytopathogenic strains of F. verticillioides: 2495, 2241; lanes 17 and $18=$ strains of $F$. oxysporum and $F$. solani.

\section{RFLP-ITS from rDNA}

Digestion with EcoRI produced two DNA fragments (possibly overlapping) of approximately $300 \mathrm{bp}$ for all the isolates (Figure 2). No digestion was observed for DraI (Figure 2). Digestion with $A l u \mathrm{I}$ resulted in fragments of approximately 450 and $150 \mathrm{bp}$ for isolates 1, 2, 3, 5, 8, 11, $12,13,15,16$, and 17 and fragments of 150 and 380 bp for isolates 4, 6, 7, 14, 9, 10, and 18 (Figure 2). Digestion with HaeIII produced fragments of 90,180 , and 300 bp for isolates 1, 2, 3, 5, 8, 11, $12,13,15$, and 16; fragments 90,180 , and 380 bp for isolates 4, 6, 7, 14, 9, and 18; fragments of 90 , 150, and $380 \mathrm{bp}$ for isolate 10; and fragments of 180 and 280 bp for isolate 17 (Figure 2). Digestion with HinfI produced two fragments (possibly overlapping) of $300 \mathrm{bp}$ for isolates 1, 2, 3, 8, 11, $12,13,14,15$, and 16; fragments of 100,200 , and 300 bp for isolates $4,5,6,7,9,10$, and 18 ; and fragments of 280 and $300 \mathrm{bp}$ for isolate 17 (Figure 3). Digestion with MspI resulted in fragments of 120,180, and $280 \mathrm{bp}$ for isolates $1,2,3,5,8,11,12,13,15$, and 16; fragments of 100 and 500 bp for isolates 4, 6, 7, 14, 9, 10, and 18; and fragments of 400 and $200 \mathrm{bp}$ for isolate 17 (Figure 3). The restriction profile for PstI produced fragments of 150 and $450 \mathrm{bp}$ for isolates 1, 2, 3, 5, 8, $11,12,13,15$, and 16 and fragments of 500 bp for isolates 4, 6, 7, 14, 9, 10, 18, and 17 (Figure 3).

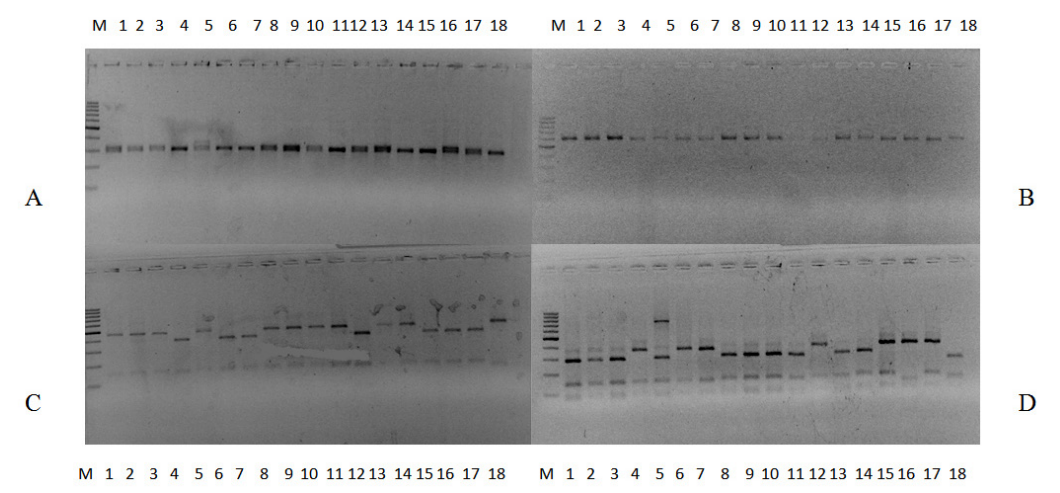

Figure 2. Restriction profiles of the internal transcribed spacer region of the rDNA of Fusarium verticillioides, F. oxysporum, and F. solani isolates with EcoRI (A), DraI (B), AluI (C), HaeIII (D) enzymes. Lane M=100-bp ladder; lanes 1-8 = phytopathogenic strains of F. verticillioides: URM5352, 3728, 3007, 5094, 3096, 2388, 2542, 2387; lanes 9-14 = clinical strains of $F$. verticillioides: 5390, 5284, 5354, 4951, 5285, FV; lanes 15 and $16=$ phytopathogenic strains of $F$. verticillioides: 2495, 2241; lanes 17 and $18=$ strains of $F$. oxysporum and $F$. solani. 

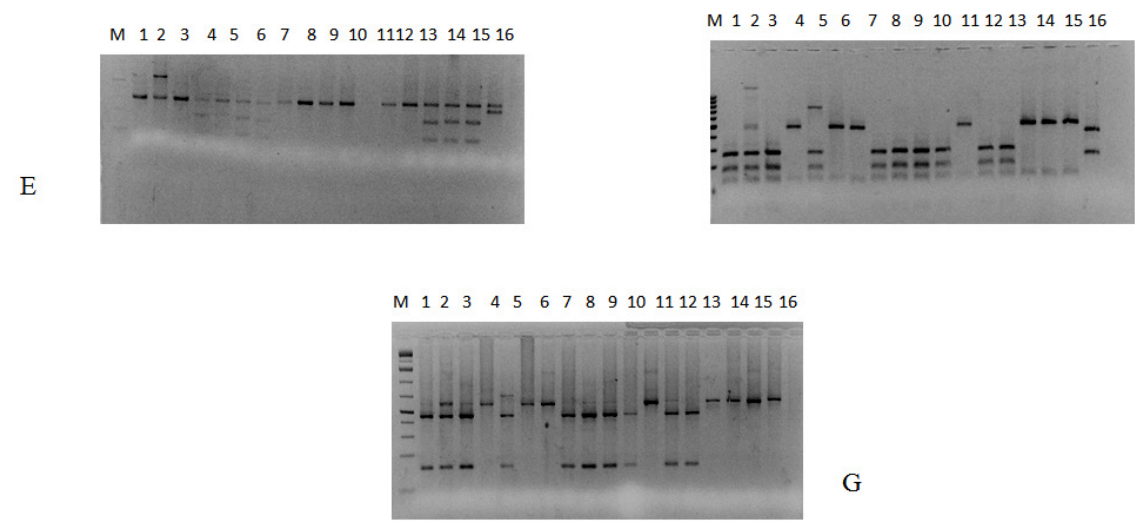

Figure 3. Restriction profiles of the internal transcribed spacer region of the rDNA of Fusarium verticillioides, $F$. oxysporum, and F. solani isolates with the HinfI (E), MspI (F), PstI (G) enzymes. Lane M=100-bp ladder; lanes 1-8 = phytopathogenic strains of $F$. verticillioides: URM5352, 3728, 3007, 5094, 3096, 2388, 2542, 2387; lanes 9-14 = clinical strains of $F$. verticillioides: 5390, 5284, 5354, 4951, 5285, FV; lanes 15 and $16=$ phytopathogenic strains of $F$. verticillioides: 2495, 2241; lanes 17 and $18=$ strains of $F$. oxysporum and $F$. solani.

Digestion with $B s h$ I produced a 500-bp fragment for isolates $1,2,3,5,8,11,12,13$, 15, 16, and 17 and a 400-bp fragment for isolates 4, 6, 7, 14, 9, 10, and 18 (Figure 4).

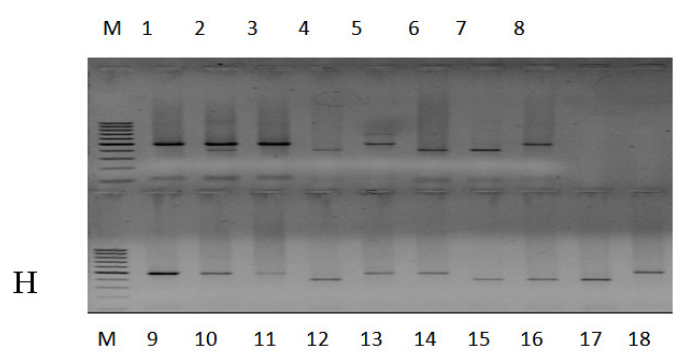

Figure 4. Restriction profiles of the internal transcribed spacer region of the rDNA of Fusarium verticillioides, $F$. oxysporum, and $F$. solani isolates with the BshI enzyme $(\mathrm{H})$. Lane $M=100$-bp ladder; lanes $1-8=$ phytopathogenic strains of $F$. verticillioides: URM5352, 3728, 3007, 5094, 3096, 2388, 2542, 2387; lanes 9-14 = clinical strains of F. verticillioides: 5390, 5284, 5354, 4951, 5285, FV; lanes 15 and $16=$ phytopathogenic strains of $F$. verticillioides: 2495, 2241; lanes 17 and $18=$ strains of $F$. oxysporum and F. solani.

\section{ISSP}

The amplification profile of the ISSP region using the EI1 primer is illustrated in Figure 5. The dendrogram that was generated from the amplification profile showed 3 groups at a similarity level of $100 \%$ for fragment size. The first group that was formed was represented by 2 isolates of phytopathogenic $F$. verticillioides (isolates 4 and 7). The second group consisted of 2 phytopathogenic $F$. verticillioides isolates (isolates 3 and 8 ) and 5 from clinical samples (numbers $11,12,13,16$, and 15). Finally, the third group was represented by 2 isolates of $F$. verticillioides, 1 obtained from a clinical sample (number 14) and 1 that was considered phytopathogenic (number 10). Isolates $1,2,6,9$, and 5 of $F$. verticillioides, and the $F$. oxysporum (number 18 ) and $F$. solani 
(number 17) isolates did not form groups, which indicated that they were genetically distant from the other analyzed isolates, and presented similarity of fragment sizes between 35 and $80 \%$. The use of this marker for isolates of $F$. verticillioides has not been reported in the literature to date.

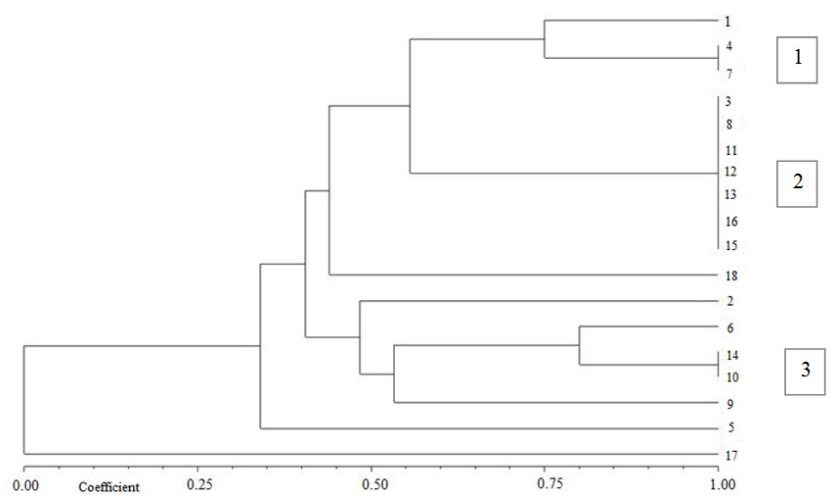

Figure 5. Dendrogram constructed by the UPGMA method, using the Jaccard coefficient from the intron splice site primer profiles with primer EI1 obtained from 16 isolates of Fusarium verticillioides (URM5352/1, 5094/4, 2542/7, 3007/3, 2387/8, 5390/11, 5284/12, 5354/13, FV/16, 5285/15, 3278/2 2388/6, 4051/14, 2241/10, 2495/9, 3096/5), F. oxysporum (URM/FO/18), and F. solani (URM/FS/17).

\section{ISSR}

Amplification profiles of the ISSR regions of Fusarium isolates using (GTG) 5 and $(\mathrm{GACA})_{4}$ primers are illustrated in Figures 6 and 7, respectively. The dendrogram showed 2 groups with $100 \%$ similarity. The first group that was formed was represented by 3 phytopathogenic $F$. verticillioides isolates (numbers 1, 3, and 5) and 5 from clinical samples (numbers $11,12,13,16$, and 15), which showed high homogeneity among the clinical samples when compared with the phytopathogenic samples. The second group was represented by 2 phytopathogenic $F$. verticillioides isolates (2 and 6).

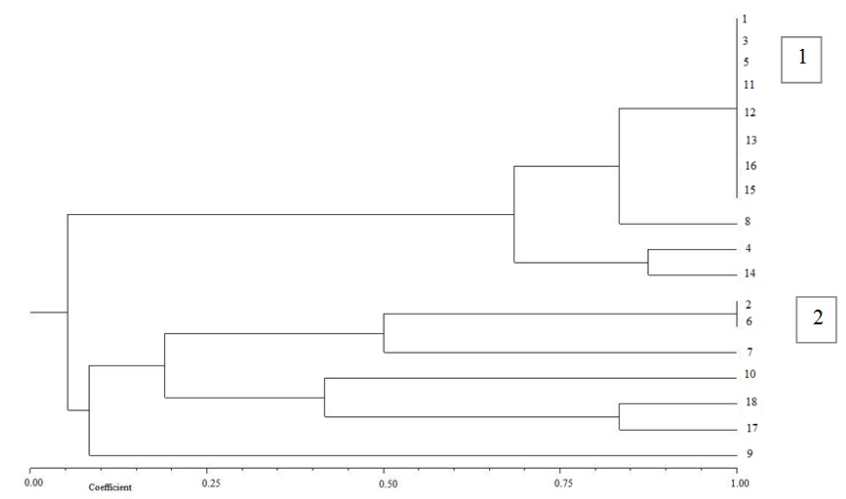

Figure 6. Dendrogram constructed by the UPGMA method, using the Jaccard coefficient from the inter-simple sequence repeat profiles with primer (GTG) $)_{5}$ obtained from 16 isolates of Fusarium verticillioides (URM5352/1, 3007/3, 3096/5, 5390/11, 5284/12, 5354/13, FV/16, 5285/15, 2387/8, 5094/4, 4051/14, 3278/2, 2388/6, 2542/7, 2241/10, 2495/9), F. oxysporum (URM/FO/18), and F. solani (URM/FS/17). 


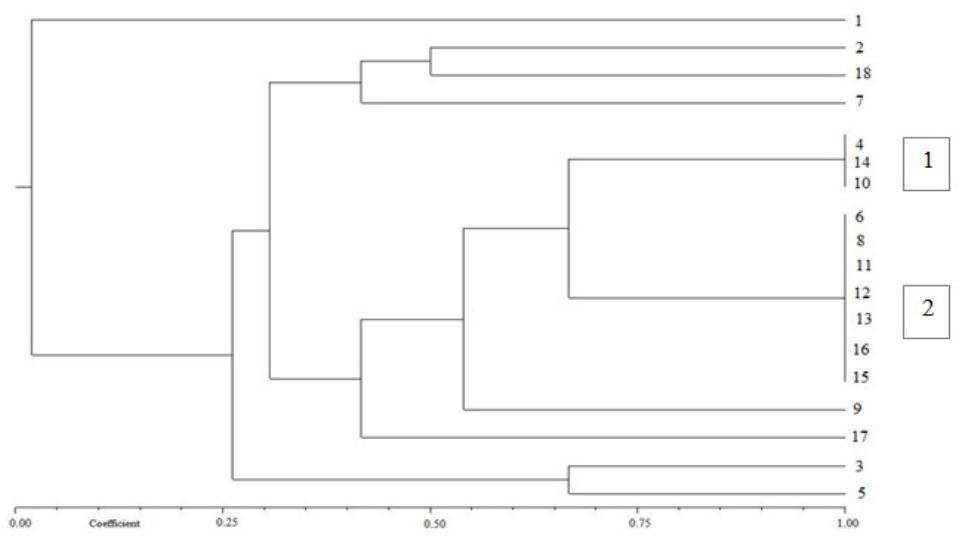

Figure 7. Dendrogram constructed by the UPGMA method, using the Jaccard coefficient from the inter-simple sequence repeat profiles with primer (GACA) 4 obtained from 16 isolates of Fusarium verticillioides (URM5352/1, 3278/2, 2542/7, 5094/4, 4051/14, 2241/10, 2388/6, 2387/8, 5390/11, 5284/12, 5354/13, FV/16, 5285/15, 2495/9, 3007/3, 3096/5), F. oxysporum (URM/FO/18), and F. solani (URM/FS/17).

\section{RAPD}

The dendrogram that was generated from amplification profiles using the RAPD OPW-6 primer (Figure 8) showed 3 groups with similarity levels of $100 \%$. The first group consisted of 2 phytopathogenic F. verticillioides isolates (numbers 1 and 3 ) and 3 isolates that were obtained from clinical samples (numbers 11, 12, and 15). The second group was represented by 2 isolates of F. verticillioides plant pathogens (numbers 2 and 9) and 2 isolates from clinical samples (numbers 13 and 16). The third group was represented by 2 phytopathogenic $F$. verticillioides isolates (numbers 4 and 10).

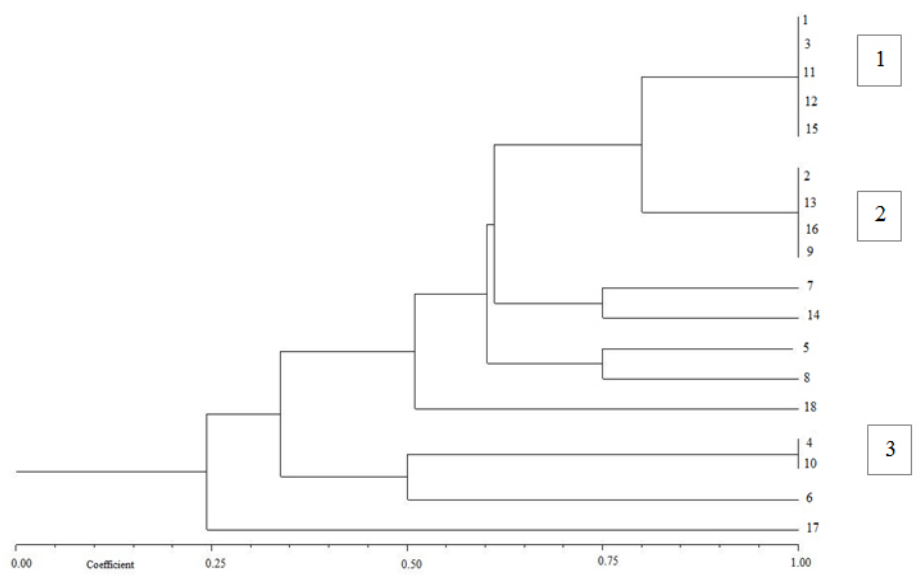

Figura 8. Dendrogram constructed by the UPGMA method, using the Jaccard coefficient based on the RAPD profiles obtained with primer OPW-6 obtained from 16 isolates of Fusarium verticillioides (URM5352/1, 3007/3, 5390/11, 5284/12, 5285/15, 3278/2, 5354/13, FV/16, 2495/9, 2542/7, 4051/14, 3096/5, 2387/8, 5094/4, 2241/10, 2388/6), F. oxysporum (URM/FO/18), and F. solani (URM/FS/17). 


\section{DISCUSSION}

Molecular techniques, especially those that involve ribosomal genes and their ITS regions, have contributed greatly to the identification of fungal species, improving taxonomic studies, and phylogenetic analysis. These in turn help considerably with carrying out morphological studies for identifying species and segregating strains, thus facilitating and enriching the study of pathogenic fungi (Driver et al., 2000; Martínez-Culebras et al., 2000; Hajek et al., 2003; Enkerli et al., 2005).

Visentin et al. (2009) treated RFLP-ITS from rDNA with AluI, MboI, HinfI, TaqI, and HaeIII to differentiate isolates of $F$. proliferatum from isolates of $F$. verticillioides. They obtained one fragment that was approximately $600 \mathrm{bp}$ in size for the $F$. verticillioides isolates and were able to differentiate the 2 species with respect to the number of base pairs after their rDNA had been digested. Dyssanayake et al. (2009) also amplified this region with primers ITS1 and ITS4 using digestion products by RsaI ScrfI, HinfI, HaeIII, and MspI. These authors obtained fragments of approximately $570 \mathrm{bp}$ for the 32 isolates of Fusarium (F. oxysporum, F. solani, and F. verticillioides).

No digestion was observed for DraI in this study, possibly because this is a rarecutting enzyme. Using the same enzyme restriction, Brasileiro et al. (2004) did not observe a cutting site for $F$. solani isolates. None of the enzymes that were used in this study was effective for separating clinical isolates from phytopathogenic isolates of $F$. verticillioides, and only HaeIII, HinfI, and MspI could be used to distinguish F. verticillioides from the $F$. solani isolate. However, the formation of distinct groups with respect to the number of fragments that was generated was observed: isolates $1,2,5,8,11,12,13,15,16$, and 17 often appeared in the same group, and isolates $4,6,7,14,9,10$, and 18 often formed a second group. There was no relationship between the groups and the source (clinical or phytopathogenic). The RFLPITS technique implies the use of only a single region of the genome and cannot be used to distinguish between pathogenic and clinical isolates of F. verticillioides. Martins (2005) could not distinguish phytopathogenic from non-pathogenic isolates of Fusarium species that were obtained from different host plants using the same technique.

The amplification profile of the ISSP regions of Fusarium isolates using the EI1 primer showed low genetic diversity among the clinical isolates in contrast to the high variability that was found among the phytopathogenic isolates of $F$. verticillioides. The presence of phytopathogenic isolates of $F$. verticillioides in groups where clinical isolates prevailed (group 2) and a co-occurrence of clinical and phytopathogenic isolates in the same group (group 3) showed that there was no genetic difference between the clinical and phytopathogenic isolates in these groups. This can be explained by the supposition raised by several authors that the isolates of $F$. verticillioides that cause human mycoses may have been acquired in the field after traumatic exposure to plants that were decomposing in the soil during tillage or other such field operations (Montiel, 2004).

Brasileiro et al. (2004) used the EI1 primer to detect intraspecific polymorphisms among isolates of $F$. solani from different hosts and reported that some isolates may have represented a clonal lineage by means of forming a group, and that other isolates of the same species showed genetic differences based on the use of this primer.

To date, this is the first report of using the EI1 primer for the genetic analysis of isolates of $F$. verticillioides. 
In contrast with the results obtained with the ISSR primers $(\mathrm{GTG})_{5}$ and (GACA), Brasileiro (2003) showed the existence of large intraspecific molecular diversity within the $F$. solani isolates, with no coincidence between the 4 groups and the geographical origin of the isolates. Barve et al. (2001) used 13 complementary ISSR oligonucleotides for the loci of microsatellites $(\mathrm{AT})_{10},(\mathrm{CT})_{10},(\mathrm{TG})_{10},(\mathrm{ACA})_{5},(\mathrm{ACC})_{5},(\mathrm{AGC})_{5},(\mathrm{ACT})_{5},(\mathrm{AGC})_{5},(\mathrm{AGG})_{5}$, $(\mathrm{AGT})_{5},(\mathrm{ATC})_{5},(\mathrm{GACA})_{4}$, and (GATA) $)_{4}$ to analyze the genetic variability of 4 strains of $F$. oxysporum $\mathrm{f}$. sp ciceris. They found that only primers $(\mathrm{AGT})_{5},(\mathrm{ATC})_{5}$, and (GATA) $)_{4}$ generated polymorphisms. Bayraktar et al. (2008) analyzed 74 isolates of $F$. oxysporum f. sp ciceris using 20 ISSR primers and confirmed that the genetic variability among the isolates was higher with respect to the different regions that were studied.

The amplification of random genomic sequences by using RAPD markers has been used to differentiate Fusarium species and to assess their genetic relationships (Assigbetse et al., 1994; Nelson et al., 1997). Kuramae and Souza (2002) estimated the genetic variability of 4 formae speciales of Fusarium oxysporum (F. oxysporum f. sp cubense, F. oxysporum f. sp lycopersici, F. oxysporum f. sp phaseoli, and $F$. oxysporum f. sp vasinfectum) and between 2 strains/races of $F$. oxysporum f. sp lycopersici by using RAPD. The genetic variability using RAPD was up to 50\% among formae speciales, and between the races 1 and 2 of $F$. oxysporum $\mathrm{f}$. sp lycopersici, it was $7 \%$. This is an evidence of the high capacity of the technique to display genetic differences even among isolates of the same forma specialis. The dendrogram that was generated from the amplification profile using the OPW-6 primer demonstrated high homogeneity among the clinical isolates. However, when compared with phytopathogenic $F$. verticillioides, this similarity was less marked than that observed by analyzing the dendrograms that were generated by the other markers $\left(\mathrm{EI} 1, \mathrm{GTG}_{5}\right.$, and $\left.\mathrm{GACA}_{4}\right)$. This was because the clinical isolates $(11,12,13,15$, and 16$)$ had $75 \%$ similarity despite the co-occurrence of clinical and phytopathogenic isolates in the same group having been more balanced than in previous analyses.

The results of this study revealed the existence of a high degree of homogeneity among clinical isolates when compared to phytopathogenic isolates of $F$. verticillioides for most of the markers that were tested. Our findings also indicated that the co-occurrence of some clinical and phytopathogenic groups can be used to reinforce the hypothesis that mycoses, in which the etiological agent is $F$. verticillioides, may be acquired in the field after traumatic exposure to plants.

\section{ACKNOWLEDGMENTS}

We thank the Mycological collection Micoteca-URM, Federal University of Pernambuco, Recife, for kindly providing the Fusarium verticillioides isolates. We also thank the Brazilian Funding Agencies CAPES and FINEP.

\section{REFERENCES}

Assigbetse KB, Fernandez D, Dubois MP and Geiger J-P (1994). Differentiation of Fusarium oxysporum f. sp. vasinfectum races on cotton by random amplified polymorphic DNA (RAPD) analysis. Phytopathology 84: 622-626.

Bacon CW and Hinton DM (1996). Fusaric acid and pathogenic interactions of corn and non-corn isolates of Fusarium moniliforme, a nonobligate pathogen of corn. Adv. Exp. Med. Biol. 392: 175-191.

Bacon CW, Glenn AE and Yates IE (2008). Fusarium verticillioides: managing the endophytic association with maize for reduced fumonisins accumulation. Toxin Rev. 27: 411-446.

Barve MP, Haware MP, Sainani MN, Ranjekar PK, et al. (2001). Potential of microsatellites to distinguish four races of 
Fusarium oxysporum f. sp. ciceri prevalent in India. Theor. Appl. Genet. 102: 138-147.

Bayraktar H, Dolar FS and Maden S (2008). Use of RAPD and ISSR markers in detection of genetic variation and population structure among Fusarium oxysporum f. sp. ciceris isolates on chickpea in Turkey. J. Phytopathol. 156: 146-154.

Bernd LP (2006). Modelagem com Ênfase no Crescimento de Fusarium verticillioides e Produção de Fumonisinas na Perda de Qualidade do Milho. Master's thesis. Universidade Estadual de Londrina, São Paulo.

Brasileiro BTRV (2003). Variabilidade Genética em Isolados de Fusarium solani Detectada com a Utilização de Marcadores Moleculares. PhD thesis. Universidade Federal de Pernambuco, Recife.

Brasileiro BTRV, Coimbra MRM, Morais Jr MA and Oliveira NT (2004). Genetic variability within Fusarium solani specie as revealed by PCR-fingerprinting based on PCR markers. Braz. J. Microbiol. 35: 205-210.

Bussab WO, Miazaki ES and Andrade DF (1990). Introdução à Análise de Agrupamentos. Associação Brasileira de Estatística, São Paulo.

de Barros Lopes M, Soden A, Henschke PA and Langridge P (1996). PCR differentiation of commercial yeast strains using intron splice site primers. Appl. Environ. Microbiol. 62: 4514-4520.

Dissanayake ML, Tanaka S and Ito S (2009). Fumonisin B(1) production by Fusarium proliferatum strains isolated from Allium fistulosum plants and seeds in Japan. Lett. Appl. Microbiol. 48: 598-604.

Driver F, Milner RJ and Trueman JWH (2000). A taxonomic revision of Metarhizium based on a phylogenetic analysis of rDNA sequence data. Mycol. Res. 104: 134-150.

Enkerli J, Kölliker R, Keller S and Widmer F (2005). Isolation and characterization of microsatellite markers from the entomopathogenic fungus Metarhizium anisopliae. Mol. Ecol. Notes 5: 384-386.

Figueira ELZ (2003). Purificação e Caracterização dos Inibidores de Amilase em Milho (Zea Mays L.) Visando o Controle de Fusarium verticillioides. Master's thesis. Universidade Estadual de Londrina, São Paulo.

Hajek AE, Jensen AB, Thomsen L, Hodge KT, et al. (2003). PCR-RFLP is used to investigate relations among species in the entomopathogenic genera Eryniopsis and Entomophaga. Mycologia 95: 262-268.

IBGE - Instituto Brasileiro de geografia e estatística (2013). Available at [http://www.ibge.gov.br]. Accessed August 26, 2009.

Kuramae-Izioka EE (1997). A rapid, easy and high yield protocol for total genomic DNA isolation of Colletotrichum gloeosporioides and Fusarium oxysporum. Rev. Unimar 19: 683-689.

Kuramae EE and Souza NL (2002). Variabilidade genética entre formae speciales de Fusarium oxysporum e raças 1 e 2 de F. oxysporum f. sp. lycopersici através de RAPD e sequências de regiões ITS e rDNA. Acta Scientiarum 24: 1481-1485.

Lieckfeldt E, Meyer W and Börner T (1993). Rapid identification and differentiation of yeasts by DNA and PCR fingerprinting. J. Basic Microbiol. 33: 413-425.

Luongo L, Maccaroni M, Ferrarini A, Vitale S, et al. (2007). Molecular characterization of Fusarium oxysporum f. sp. melonis. J. Plant Pathol. 89: 46.

Marasas WFO, Thiel PG, Rabie CJ, Nelson PE, et al. (1986). Moniliformin production in Fusarium section Liseola. Mycologia 78: 242-247.

Martínez-Culebras PV, Barrio E, García MD and Querol A (2000). Identification of Colletotrichum species responsible for anthracnose of strawberry based on the internal transcribed spacers of the ribosomal region. FEMS Microbiol. Lett. 189: 97-101.

Martins MK (2005). Variabilidade Genética de Isolados de Fusarium spp. e Estudo da Interação com a Planta Hospedeira. $\mathrm{PhD}$ thesis. Escola Superior de Agricultura Luiz de Queiroz, ESALQ, Piracicaba.

Meirelles PG (2005). Fusarium verticillioides: Caracterização Molecular e Detecção em Milho Através de Ensaio Imunoenzimático. Master's thesis. Universidade Estadual de Londrina, Londrina.

Meyer W and Mitchell TG (1995). Polymerase chain reaction fingerprinting in fungi using single primers specific to minisatellites and simple repetitive DNA sequences: strain variation in Cryptococcus neoformans. Electrophoresis 16: $1648-1656$

Mirete S, Vázquez C, Mulè G, Jurado M, et al. (2004). Differentiation of Fusarium verticillioides from banana fruits by IGS and EF-1 $\alpha$ sequence analyses. European J. Plant Pathol. 110: 515-523.

Montiel HV (2004). Patógenos emergentes en micosis cutáneas y sistémicas. Dermatol. Venezolana 42: 4-18.

Nagarajan G, Kang SW, Nam MH, Song JY, et al. (2006). Characterization of Fusarium oxysporum f. sp. fragariae based on vegetative compatibility group, random amplified polymorphic DNA and Pathogenicity. Plant Pathol. J. 22: 222-229.

Nelson AJ, Elias KS, Arévalo GE, Darlington LC, et al. (1997). Genetic characterization by RAPD analysis of isolates of Fusarium oxysporum f. sp. erythroxyli associated with an emerging Epidemic in Peru. Phytopathology 87: 1220-1225.

Pamphile JA and Azevedo JL (2002). Molecular characterization of endophytic strains of Fusarium verticillioides (=Fusarium moniliforme) from maize (Zea mays L). World J. Microbiol. Biotechnol. 18: 391-396.

Patiño B, Mirete S, Vázquez C, Jiménez M, et al. (2006). Characterization of Fusarium verticillioides strains by PCRRFLP analysis of the intergenic spacer region of the rDNA. J. Sci. Food Agr. 86: 429-435. 
Ramos ATM (2008). Levantamento da Micoflora de Grãos Ardidos de Milho e Avaliação da Resistência Genética à Fusarium verticillioides. Master's thesis. Escola Superior de Agricultura "Luiz de Queiroz", Piracicaba.

Reynoso MM, Chulze SN, Zeller KA, Torres AM, et al. (2009). Genetic structure of Fusarium verticillioides populations isolated from maize in Argentina. Eur. J. Plant Pathol. 123: 207-215.

Rohlf FJ (1988). NTSYS-PC. Numerical Taxonomy and Multivariate Analysis System. Version 2.1. Exeter Software, New York.

Sambrook J, Fristsch EF and Maniats T (1989). Molecular Cloning. A Laboratory Manual. Cold Spring Harbor, New York.

Sartori AF, Reis EM and Casa RT (2004). Quantificação da transmissão de Fusarium moniliforme de sementes para plântulas de milho. Fitopatol. Bras. 29: 456-458.

Schiabel VC (2004). Genética e Toxicidade de Fusarium verticillioides em Grãos de Milho (Zea Mays L.) Sob Plantio Direto e Convencional. Master's thesis. Universidade Estadual de Londrina, Londrina.

Singh BP, Saikia R, Yadav M, Singh R, et al. (2006). Molecular characterization of Fusarium oxysporum f. sp. ciceri causing wilt of chickpea. Afr. J. Biotechnol. 5: 497-502.

Tezcan G, Ozhak-Baysan B, Alastruey-Izquierdo A, Ogunc D, et al. (2009). Disseminated fusariosis caused by Fusarium verticillioides in an acute lymphoblastic leukemia patient after allogeneic hematopoietic stem cell transplantation. $J$. Clin. Microbiol. 47: 278-281.

Visentin I, Tamietti G, Valentino D, Portis E, et al. (2009). The ITS region as a taxonomic discriminator between Fusarium verticillioides and Fusarium proliferatum. Mycol. Res. 113: 1137-1145. 